\title{
Ekkehard König Definite articles and their uses
}

\section{Diversity and patterns of variation}

\begin{abstract}
The goal of this paper is to provide the basic outline of a typological study of definite articles, on the basis of both formal and notional criteria, with a focus on European languages. In contrast to earlier contributions to this topic and to recent, more comprehensive typological studies, more attention will be paid to (i) the problems of providing a clear semantic basis for the comparison and (ii) the reconstruction of plausible historical developments, following the leads of Greenberg (1990) and others. In addition to developing a more fine-grained typology of definite articles, the paper will also show that, even in the restricted area of Europe, we find a remarkable diversity in the meaning and use of definite articles.
\end{abstract}

Keywords: formal and notional criteria for comparison, types of definite articles, diversity of forms and use

\section{Introduction}

One of the basic assumptions of structuralism (cf. Lazard, 2012), viz., the assumption of the sign as an inseparable union of acoustic image and concept (signifiant versus signifié), has often been abandoned in linguistics, especially in comparative and typological studies. Only through this change in the theoretical foundations of linguistics has it become possible to base the comparison of languages not only on formal but also on notional criteria and to compare the different ways in which specific meanings are encoded in languages. In the domain under discussion, i.e., definite articles, we can base a comparison on suitable formal criteria and investigate different meanings and uses of comparable forms (e.g., constituents of noun phrases or nouns, preceding or following a noun) or on notional

Ekkehard König, Free University of Berlin and Albert-Ludwigs-University Freiburg, Germany, koenig@zedat.fu-berlin.de

Ә Open Access. () 2018 Ekkehard König, published by De Gruyter. (c) BY-NC-ND This work is licensed under the Creative Commons Attribution-NonCommercial-NoDerivatives 4.0 License.

https://doi.org/10.1515/9783110607963-006 
criteria like "definiteness" and investigate the different ways of encoding this notion. In further illustration of the second approach, let me briefly mention that the list of formal properties that have been enumerated as markers of definiteness includes the following: word order, sentential stress, adnominal pronouns (Louagie and Verstraete 2015), case, number marking, aspect and topic markers. Both of these approaches and their combination require, however, clear definitions and explications of their basic terms "definite article" and "definiteness".

The goal of this paper is to provide the basic outline of a typological study of definite articles, on the basis of both formal and notional criteria, with a focus on European languages. In contrast to earlier contributions to this topic (Krámský 1972; Nocentini 1996) and to recent, more comprehensive typological studies (Dryer 2005, 2014), more attention will be paid to (i) the problems of providing a clear semantic basis for the comparison and (ii) the reconstruction of plausible historical developments, following the leads of Greenberg (1990), Hawkins (2004) and Heine and Kuteva (2006).

\section{Definition, identification, establishing comparability}

Definite articles have traditionally been identified and described for modern European languages (Germanic, Romance, Celtic, Basque, Hungarian, Bulgarian) and for Semitic languages. Moreover, emergent articles can be found in the periphery of Europe, i.e., Finnish (Chesterman 1991), Sorbian and Polish (Heine and Kuteva 2006). In fact, definite articles and their contrasts to indefinite ones are often considered to be one of the most characteristic features of Europe as a linguistic area (cf. Haspelmath 2001). The relevant grammatical category was absent, however, in earlier stages of Indo-European languages, with the exception of Classical, post-Homeric Greek. Typological studies have recently shown that something like definite articles is also found elsewhere (in Central Africa, MesoAmerica and the Pacific).

On the basis of his rich collections of data, Dryer $(2005 ; 2014)$ has provided a comprehensive description of the diversity found in the forms and uses of definite articles in the world. In one of his contributions to the World atlas of language structures, he identifies definite articles cross-linguistically on the basis of the following syntactic criteria: they are free or bound morphemes, constituents of noun/determiner phrases, derived but different from adnominal demonstratives, typically forming an opposition with indefinite articles, and they cannot occur on 
their own (i.e., they cannot be heads in the traditional sense of the term) (Dryer 2005: 154). These formal criteria are clearly applicable to the invariant pre-nominal article in English (the), to the definite articles in French, which inflect for gender (le, la) and number (le, les) and to the definite articles in German, which inflect for gender (der, die, das), number (die) and case (der, des, dem, den and so on). They also apply to the post-posed articles of Scandinavian (-en), Bulgarian ($t a,-t o,-t e)$, Romanian (-ul, $-a$ and so on) and Basque (- $a,-a k)$.

Dryer's semantic criteria, by contrast, are much more general and less restrictive: definite articles encode "definiteness" and have at least an anaphoric use, i.e., they can have the same referent as an antecedent found in a preceding sentence or text. This definition and the typology it underlies have been criticized as being too broad and too vague and as being therefore applicable to languages which do not meet the criteria generally subsumed under the term "definiteness", such as "uniqueness", "familiarity" and "inclusiveness" (cf. Davis, Gillon and Matthewson 2014). In a more elaborate follow-up article to the brief general sketch required by the World atlas of language structures format, Dryer (2014) explains that he wanted to uncover a wider diversity in the use of definite articles than is presented in earlier descriptions and to show that languages with a binary contrast between definite and indefinite articles of the sort found in English are uncommon outside of Europe and the Middle East.

As already mentioned, the main focus of my paper is on European languages. Its goal is to establish more solid semantic foundations for a comparative study of definite articles and to reconstruct the development of these expressions on the basis of available data and plausible processes of semantic change and grammaticalization. The implementation of these goals will be a first step toward a more fine-grained typology of definite articles and ultimately provide a better basis for extending the scope of such a typology to the specific articles of Polynesian languages (cf. Mosel and Hovdhaugen 1992; Moyse-Faurie 1997) and other systems discussed in Dryer (2014). Moreover, it will also be pointed out that, even in the restricted area of Europe, we find a remarkable diversity in the use of definite articles.

The concept "definiteness" that is used in the label for the relevant class of functional expressions is by no means a basic or primitive concept and therefore in need of explication. Using this label in the analysis of articles does not say much more than that an expression of a specific language is translated by the definite article the in English. Various attempts to explicate this notion in terms of more elementary ones can be found in philosophical studies (Russell 1905; Frege 1984; Neale 1990), in linguistic studies such as Hawkins (1978) and Abbott (2004) and, more recently, in formal semantic studies such as Elbourne (2010; 
2012), Gisborne (2012) and Coppock and Beaver (2015). This is not the place for a detailed discussion of the relevant formalisms. So let me just point out that the more elementary notions used in the relevant explications are the following: "uniqueness", “salience”, “existence”, “identifiability” and "inclusiveness”. of these elementary notions, "uniqueness" is the most important one. Whenever we use a definite article, as in (1), we presuppose that reference is made to an object or entity that is unique and therefore clearly identifiable in a given context.

(1) a. Could you pass me the salt?

b. Let's have a look at the church!

c. The book I bought yesterday is on the short-list for a prize.

An additional criterion of salience is important for those cases where several objects meet the description 'church' in (1b) or 'book I bought yesterday' in (1c). In those cases, it has been shown that interlocutors, even at an early age, look for an additional property that distinguishes one entity from the others. ${ }^{1}$ Furthermore, in nearly all cases where a unique object is referred to, there is also a presupposition of existence. Nevertheless, it is possible to construct examples where this presupposition is not met, like in (2), where a book has been written by two authors so that there is no "single author" (Coppock and Beaver 2015).

(2) Houellebecq is not the only author of La vie en rose.

The criterion of inclusiveness or exhaustivity is relevant for plural contexts, where the definite article is quite similar to universal quantifiers like all. A request like (3) would generally be meant to include all the cushions outside.

(3) It is raining. Could you bring in the cushions!

Since plural contexts pose additional problems, we will not consider them any further in what follows. Nor will we consider such quantificational uses as are exemplified by (4), where the definite article is in the scope of and bound by the quantifier each.

1 The additional pragmatic criterion of salience does not provide the required solution for counterexamples to the uniqueness requirement like he is standing at the corner of the intersection (Coppock and Beaver 2015: 394).The relevant examples have been discussed in a wide variety of studies and, apparently, constitute a limited but systematic set of counterexamples to the uniqueness requirement. 
(4) The mother of each girl was there when their bus left.

For all of the concepts discussed above, there are precise formal explications in the relevant literature - in some cases, controversial in their details. In summary and without going into the details of a rich literature and complex discussion, we can say that it is the presupposition of uniqueness that is the most important ingredient of the meaning of definite articles. This assumption of uniqueness guarantees that the referent is identifiable for the interlocutor. In the terminology of pragmatics, more specifically in the view of Relevance Theory (Sperber and Wilson 1996), definite articles “come with a guarantee of identifiability”.

Given this requirement of uniqueness in a given context, let us now consider the various ways in which a context may identify a unique object. The most important contextual types are described in the following list:

(5) presupposition of uniqueness and identifiability in a certain context:

a. identification through the situation of speech or universe of discourse (situational use, visibility or general background knowledge)

b. identification through sufficient description (cataphoric use)

c. identification by the preceding context (anaphoric use)

d. identification through appeal to personal memory, partial description (recognitional use, emploi mémoriel)

e. identification by association with an identifiable entity (associative use)

These different ways of contextually identifying the referent of a definite article can be illustrated by the following examples:

(6) a. Pass me the salt. Today the sun is shining. The Pope will come to Paris.

b. The book I bought yesterday is under discussion for the Nobel Prize.

c. Somebody stole my bike yesterday but they have already found the thief.

d. You remember the restaurant we went to recently. That is where I found a wallet.

e. We laid out the picnic. The coffee was still warm.

These are the five context types most frequently distinguished in the literature (cf. Hawkins 1978; Löbner 1985; Himmelmann 1998; De Mulder and Carlier 2011). In (5) and (6), they are listed in the order of their historical development. The most basic way in which a referent might be unique and thus identifiable is its presence in the context of speech, as in (1a) and (6a). A slight extension of this domain of identification then leads to referents that are unique in a universe of discourse: 
the Pope, the sun, the government, the weather and so on. ${ }^{2}$ We know that there are many suns in the universe but there is only one that is of interest in the context of our weather. A dedicated militant of a political party will simply speak of "the party", whenever she makes reference to her own group and can even give that identification a high scalar value by stressing the definite article (THE [ði:] party). In the anaphoric and cataphoric uses of the definite articles, the referents are given in the co-text, in the preceding co-text for anaphoric reference, as in (6c), and in the following co-text for cataphoric reference, as in (6b). Note that definite descriptions, i.e., the identification of a referent through a description of its salient properties, is simply regarded here as an instance of cataphora. The recognitional use (emploi mémoriel) requires a search in the memory of interlocutors rather than in the co-text or the non-verbal context. According to Himmelmann (1997), this use of demonstratives has played the decisive role in the development of the definite article. A characteristic feature of this use is the explicit appeal to the hearer to search for the relevant context in his/her memory. Finally, the associative use requires that a referent is identifiable through its association with another one given in a context (cf. Clark and Marshall 1981). There are many relations between entities that provide such a bridge: part-whole, as in (6e), or action-instrument, as in examples like (7).

(7) Our neighbor was killed. The weapon was found two days later.

\section{Origin and historical development}

Let us now consider in how far the preceding ordering of relevant contexts for the use of definite articles has historical relevance and squares with the historical evidence provided by relevant data. There is clear historical evidence and general agreement that definite articles - at least in Europe - derive from adnominal demonstratives. This development is a younger phenomenon, only (post-Homeric) Greek and Old Norse had articles among the ancient languages of Europe. Right from the start we must admit, though, that the available historical information is limited and does not enable us to clearly reconstruct and document the

2 One of the reviewers pointed out that absolute unica or entities conceived as such (church, sun) could appear without articles in older stages of European languages. It is quite plausible to assume that, in those stages, the relevant nouns were used as proper names. 
relevant processes of granmaticalization so that we partly have to rely on synchronic evidence.

In his frequently cited paper, Greenberg (1990) distinguished three stages in the development of definite articles from demonstratives, as in Table 1.

Tab. 1: Greenberg's (1990) stages of the development of definite articles

\begin{tabular}{llll}
\hline Stage 0 & Stage 1 & Stage 2 & Stage 3 \\
\hline distal demonstratives & definite article & general article & noun marker \\
\hline
\end{tabular}

In Hawkins (2004) and Heine and Kuteva (2006), this schema is further elaborated to include four stages. In our elaboration of these schemata, we will distinguish five stages, including the use of demonstratives as a separate stage and the development of specific articles in Polynesian languages as a further development, whose details are not very clear, however. The two hierarchies in (8) and (9) roughly characterize the co-evolution of form and meaning in the historical development of definite articles, exclusive of Greenbergs final stage.

(8) demonstratives $>$ strong article $>$ weak article $>$ generic article $>$ specific article

The labels listed and ranked in (8) correspond to the uses in (9). ${ }^{3}$

(9) exophoric $>$ endophoric (anaphoric/cataphoric) $>$ associative $>$ generic/abstract $>$ specific

Let us now take a detailed look at labels and uses, at the relevant historical developments and at individual expressions manifesting a particular use. ${ }^{4}$ It is an essential property of demonstratives that they have an exophoric, pointing and contrastive use. They can be used with a pointing gesture and identify entities in

3 What the chains described in (8) or (9) primarily indicate is the development of a new use. Languages differ, however, in whether the use to the left is kept or not in addition to acquiring the new one, i.e., the relevant articles differ in their degree of grammaticalization. In contrast to English, definite articles can still be used exophorically in German and the weak articles of Frisian can still be used for unique entities (cf. Ebert 1970).

4 A more detailed discussion and documentation of the relevant semantic changes, of controversies and relevant data is presented in De Mulder and Carlier (2011). 
contrast to others (e.g., I want THIS book [gesture] and not the other). Demonstratives of all syntactic and semantic types generally have anaphoric and cataphoric uses in addition to the exophoric one but what is maintained in the two endophoric uses of demonstratives is the contrastive element (e.g., yesterday I bought a book and THIS book I will give to my mother), which is no longer expressed by definite articles like English the. ${ }^{5}$ So in the first stages of their development to articles, demonstratives do not only lose their exophoric (gestural) use but also their contrastive meaning. This is exactly the reason why an anaphoric use of an adnominal demonstrative is not a sufficient condition for using the term "definite article" for the relevant expression.

There is good evidence for Romance languages that it is typically the distal demonstrative (Latin ille) that gives rise to definite articles (French le/la/les). Given, however, that demonstratives invariably also have an anaphoric use, it should not come as a surprise that some articles seem to be based more clearly and exclusively on this anaphoric use. This is the case not only for those articles derived from Latin ipse (es, sa in Western Catalan and Sardinian) but also for combinations like ledit 'said' in Middle French and all combinations of verbs of saying with demonstrative elements (German der erwähnte/besagter 'said', English the aforementioned) or from verbs of saying alone (cf. De Mulder and Carlier 2011). Mention should also be made in this connection that the deictically neutral demonstrative $c e$ in French manifests the properties of the first stages in the development of a demonstrative to a definite article, i.e., the anaphoric and the anamnestic (recognitional) use (cf. De Mulder and Carlier 2006).

German and Dutch manifest another interesting, intermediate stage in the development of demonstratives to definite articles: reduced forms of the demonstratives, identical to the definite articles, have an anaphoric pronominal use, in which they contrast with personal pronouns in the choice of the antecedent they relate to. Consider the minimal pairs in German in (10) and (11).

(10) German

a. Der Hausbesitzer informierte den Handwerker, bevor er in $_{i}$ ach Hause ging.

'The owner of the house informed the workman, before going home.'

b. Der Hausbesitzer informierte den Handwerker, ${ }_{j}$, bevor der ${ }_{j}$ nach Hause ging.

'The owner of the house informed the workman, before he went home.'

5 In contrast to the invariant definite article the in English, its German counterparts still have an exophoric use: ich möchte DAS Buch 'I would like to have that book'. 


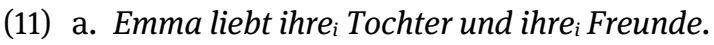

'Emma loves her daughter and her (own) friends.'

b. Emma ${ }_{i}$ liebt $\left[\text { ihre }_{i} \text { Tochter }\right]_{j}$ und deren Freunde.

'Emma loves her daughter and her (daughter's) friends.'

These examples show that the relevant reduced demonstratives are used as pronouns rather than adnominally. Moreover, they are used anaphorically like personal pronouns, with which they contrast in (10) and (11). In contrast to the latter, however, they do not pick out the subject as their antecedent but another one, viz., one that the personal pronoun could not relate to without ambiguity, as indicated by the co-indexation and the English translation. What we find here is a change from the nominal exophoric use of demonstratives to an anaphoric one, with the same formal reductions also found in the definite article, accompanied by a loss of the exophoric use only, i.e., without a loss of the contrastive component. This component of contrast now manifests itself in a differential choice, i.e., in the choice of an antecedent different from that made by personal pronouns. The question of how this choice is best described (obviative, non-subject, nontopical antecedent) is a matter of some controversy and will not be pursued any further at this point (for a more detailed discussion, cf. Bosch, Rozario and Zhao 2003; Bosch, Katz and Umbach 2007).

The relevant step in the change from an exophoric to an anaphoric or cataphoric use is the fact that the search for a unique referent is transferred from an external situation to a search in the co-text, either preceding or following. Only if this change is accompanied by a loss of the contrastive meaning can we speak of an emergent article, however. In contrast to the anaphoric use, the cataphoric use provides an identification via a description, i.e., by a relative clause or any other nominal adjunct. In German, there are combinations of articles and distal demonstratives which, through their composite forms, clearly illustrate the transition from demonstrative to definite article in the cataphoric use (der-jenige 'he who', die-jenige 'she who'). These forms are typically employed in cataphoric contexts, i.e., with a following relative clause (e.g., diejenigen Studenten, die noch nicht bezahlt haben, möchten dies bitte bald tun 'the students who have not paid yet are kindly asked to do so immediately'), even though their anaphoric use is also marginally possible.

The next stage in the development of definite articles involves a major step in the availability of a context for identification, from an external, situational or textual context to a more abstract context of association, of memorizing or of general availability in a universe of discourse. It is here that we find the associative and recognitional use (emploi mémoriel) of articles, as well as those cases where 
the cultural or local context provides a unique referent. The associative use, as in (6e), is often regarded as the crucial step in the development of a definite article, since this use is not available for demonstratives.

In this domain beyond the anaphoric and cataphoric uses of demonstratives and articles, some languages (varieties of Low German, Frisian, Scandinavian and Standard German) draw a distinction between two types of definite articles: a strong one (pragmatic definiteness) and a weak one (semantic definiteness) (cf. Heinrichs 1954; Ebert 1970; Löbner 1985, 2011; De Mulder and Carlier 2011; Schwarz 2013, 2014). On the basis of the available literature, the distinction in the use of these two definite markers can roughly be described as follows: (i) the strong article manifests the situational use, the anaphoric one, including pseudoanaphors (e.g., Bill left - the fool had forgotten his money) and typically also the cataphoric one; (ii) the weak article occurs in associative contexts, in reference to unique entities in the universe of discourse, as well as in generic contexts. In Standard German the regularities are somewhat more complex (cf. Bosch 2013; Schwarz 2013; 2014). A distinction of this kind only shows up in connection with the fusion of definite articles and prepositions, subject to additional phonological constraints (im, am, zum, vom, beim, zur, ins, ans), which is in contrast to the strong, non-fused form. The latter manifests the anaphoric and cataphoric uses whereas the fused forms typical exhibit the associative use, as well as the use related to unique referents given in the abstract universe of discourse, and also occur in generic sentences. In minimal pairs like (12), the weak article refers to an abstract institution whereas the strong article refers to a specific building, similarly to the use versus non-use of definite articles in English.

(12) a. Karl geht noch zur Schule.

'Charles still goes to school.'

b. Karl ging zu der Schule hin.

'Charles went to the school building.'

c. Karl ist im Gefängnis.

'Charles is (doing time) in prison.'

d. Karl ist jetzt in dem Gefängnis.

'Charles is now inside the prison.'

e. Ich möchte zur Kirche gehen.

'I would like to go to church.' 
Examples like (12) also show that weak definites in their fused forms have special semantic properties in German, in addition to their contextual restrictions. As pointed out by Bosch (2013), they often involve some semantic enrichment over and above their local information, they lack the existential presupposition typically found in connection with strong definites and the identification of a referent is typically not required or possible. Sentences like (12a) and (12c) identify a location but also express the activity associated with that location. And an utterance like (12e) could meet with a response pointing out that there is no church in the relevant area.

The next step articles typically take in extending their use is the domain of abstract terms and generic sentences. Note that, in contrast to (13) and (14), all preceding examples were episodic sentences. French and Italian are clear examples of languages where generic sentences and expressions denoting abstract terms require the definite article whereas this is only optional in German and unusual in English. ${ }^{6}$ In the abstract and generic use, reference is made to kinds and to abstract entities (cf. Behrens 2005).

(13) a. La solitude est difficile à supporter. (French)

b. (Die) Einsamkeit ist schwer zu ertragen. (German)

c. Loneliness is difficult to live with.

(14) a. Les faucons sont des oiseaux de proie. (French)

b. (Die) Falken sind Raubvögel. (German)

c. Falcons are predator birds.

The final stage, i.e., the one that leads from definite articles as found in Europe to specific articles, is based on highly controversial assumptions and no convincing semantic reconstruction has been proposed so far. An extension in the use of definite articles to merely expressing specificity is assumed in Hawkins (2004: 85) and subsequently adopted in Heine and Kuteva (2006: 103). This assumption is, however, rejected by Himmelmann (1997: 107), who assumes that specific articles evolve directly from demonstratives.

6 One of the reviewers pointed out that, in Spanish and French, generic uses of definite articles were already observable in the very first texts, although they were less frequent. This greater time depth of the generic use offers an explanation for their obligatory nature in current use but throws some doubt on the historical scenario assumed above. 
Let us now look at some of the relevant languages and data. Specific articles are found in Polynesian languages and also in a few Melanesian ones (cf. Mosel and Hovdhaugen, 1992; Moyse-Faurie 1997). The relevant articles in Polynesian languages (le in Samoan and East Futunan, te in Maori and East Uvean), for example, are not only used in contexts which require definite articles in European languages but also for the introduction of a discourse referent and for contexts where an indefinite article would be used in most European languages. The opposition between a specific and a non-specific use of the indefinite article in English, for example, is expressed by the contrast in (15) between specific le and nonspecific se in East Futunan.

(15) East Futunan

a. E iai le Pilitania e fia 'avaga a malia mo ia.

'There is an Englishman Malia wants to marry.'

b. E faka 'amu a Malia ke 'avaga mo se Pilitania.

'Mary would like to marry an Englishman.'

(Moyse-Faurie, p.c.)

For such contrasts, the terms "specific" versus "non-specific" articles are indeed appropriate: the article le has lost the uniqueness presupposition but has retained the existential implication typically associated with the definite article. So far, we can still speak of semantic loss or erosion. On the other hand, specific articles are also used for emphatic (contrastive) assertion of membership in a class in contrast to another, as in (16) from East Uvean.

(16) East Uvean

Ko te fafine ia, mole ko te tagata.

'It is a woman, not a man.'

(Moyse-Faurie 2016: 77)

An analysis which sees specific articles as further developments of definite articles as they are found in Europe has to assume that these articles have not only lost their essential property, i.e., the presupposition of uniqueness, but have also re-acquired the contrastive use of demonstratives. Another explanation for the various uses of specific articles could be sought in the conceptualizations they express. We could assume, for example, that classes are conceptualized as individuals in Polynesian languages but further evidence would have to be provided 
for that assumption. On the basis of such an assumption, the use illustrated by (16) would express the contrast between two individuals rather than between two members of two classes. It is therefore not clear whether specific articles are really a further development of definite articles. Given that our perspective is primarily a typological one, we will not pursue this question any further.

Analogously to the labels and functions ordered in the two hierarchies in (8) and (9), we can also now rank the relevant semantic changes (extension of contexts) as in Table 2.

Tab. 2: Semantic changes in the development of definite articles

\begin{tabular}{|c|c|c|c|c|}
\hline Stage 1 & Stage 2 & Stage 3 & Stage 4 & Stage 5 \\
\hline $\begin{array}{l}\text { exophoric } \\
\text { contrastive }\end{array}$ & $\begin{array}{l}\text { anaphoric } \\
\text { cataphoric } \\
\text { (sufficient de- } \\
\text { scription) } \\
\text { employ mémoriel } \\
\text { (loss of contras- } \\
\text { tive and exo- } \\
\text { phoric use) }\end{array}$ & $\begin{array}{l}\text { abstract context } \\
\text { universe of dis- } \\
\text { course } \\
\text { extension of con- } \\
\text { text from co-text } \\
\text { to abstract uni- } \\
\text { verse of dis- } \\
\text { course }\end{array}$ & $\begin{array}{l}\text { generic, abstract } \\
\text { non-referential } \\
\text { non-episodic } \\
\text { contexts }\end{array}$ & $\begin{array}{l}\text { specific } \\
\text { contrastive } \\
\text { loss of uniqueness }\end{array}$ \\
\hline
\end{tabular}

So far, nothing has been said about a use found in some languages (Greek, Catalan, Romanian and Albanian; optionally in German and Italian) where definite articles are redundant, viz., their use with proper names (cf. Nocentini 1996). In Modern Greek, definite articles are not only used before proper names of people but also together with place names, with the names for planets, months, holidays and years, with generic and abstract terms and even in combination with adnominal demonstratives. In German and Spanish, the use of articles in combination with some of these names is possible but often involves a slight change of meaning. A pejorative, honorific component or an implicature of familiarity is added. Most of these uses are excluded in English and French. ${ }^{7}$ Interestingly enough, the use of definite articles with proper names is excluded in Standard Basque, a language which completely excludes bare nominal phrases in argument positions (Etxebarria 2014). For these and other reasons, it cannot be assumed that the redundant use of definite articles is the result of a further development at the right

7 In French and Italian, place names (towns, cities) can only combine with the definite article if they are followed by a relative clause (e.g., le Paris que j'avais connu il y a vingt ans 'the Paris that I knew twenty years ago'), unless the article is an integral part of the name (e.g., La Hague). 
end of our scale. The development of totally redundant uses of definite articles cannot be analyzed as being part of a wide-spread chain of grammaticalization but must be a lateral development.

\section{Syntactic diversity in the use of definite articles}

After this brief sketch of semantic differentiations described in terms of grammaticalization let us now look at some of the most striking parameters of variation in the syntax of definite articles. In the available typological surveys (Krámský 1972; Lyons 1999; Dryer 2005), the following parameters of variation are invariably mentioned: availability of articles, one or two types, free form versus affix, interaction with morphological categories and delimitation from demonstratives. More detailed studies on individual phenomena have additionally revealed the insights in Sections 4.1 to 4.4.

\subsection{Multiple use of definite articles in nominal phrases}

This is found, inter alia, in Albanian, Modern Greek, Yiddish, Romanian, Arabic, Scandinavian and Bavarian (cf. Plank 2003). This multiple occurrence is connected with the normal and special ordering of adjectives, as in (17). In French, superlatives require a double use of the definite article (e.g., l'étudiant le plus intelligent 'the smartest student').

(17) Modern Greek

a. i kondés fústes 'the short skirts'

b. i fústes i kondés 'the short skirts'

c. i kondés i fústes 'the short skirts' (Joseph and Philippaki-Warburton 1987: 51) 


\subsection{Co-occurrence with demonstratives, possessives or both}

This is found, inter alia, in languages like the following: Italian, Modern Greek, Hungarian, Chamicuro (Amazonian), Polynesian, Tîrî (Melanesian), Abkhaz and Guarani (cf. Haspelmath 1999). This double marking of definiteness, as in (18), seems to be connected with the time of development of the definite article.

(18) Italian

Ho perduto la mia giacca.

'I’ve lost my jacket.'

\subsection{Differential/extended use with respect to semantic context (generic, mass, deixis, proper nouns)}

This can be observed in European languages. As already pointed out, languages differ with respect to the extension of their use to certain contexts. From a synchronic perspective, we can rank languages according to the frequency with which definite articles are used, since there are more or less clear subset relations for restrictions on the omission of the definite article (cf. Longobardi 1994, 2001; Dahl 2004; Behrens 2005) - which, for some languages, yields roughly the hierarchy in (19).

(19) Greek $>$ Basque $>$ French, Hungarian $>$ German $>$ English

\subsection{Use inside of adpositional phrases}

As pointed out by Himmelmann (1998), definite articles are more exceptional in prepositional phrases than in noun phrases. This can clearly be demonstrated for languages like Romanian, Albanian, Tagalog, Bantu and Germanic and for locative or temporal nouns in Polynesian languages. Such tendencies can also be observed in specific constructions in many European languages. Himmelmann (1998) offers a historical explanation for this asymmetry: definite articles develop relatively late and the article-less syntax of prepositional phrases is retained.

Fine-grained comparisons between European languages clearly reveal such asymmetries but the differences tend to be construction-specific and no generalizations are possible even across genealogically related languages. In (20) to (23), a few examples concerning French, German, Italian and English are given. 
(20) smell: English $=$ German $=$ Italian $\neq$ French

a. This smells of cow, cat, cabbage, flowers.

b. Das riecht nach Kuh, Katze, Kohl, Blumen.

c. Ça sent la vache, le chat, le chou, les fleurs.

(21) manner of motion: English $=$ French $=$ Italian $\neq$ German

a. go by train/bus/plane/boat/on foot

b. mit dem Zug/Auto/Fahrrad/Flugzeug/Schiff reisen/fahren (versus zu Fuß gehen)

c. aller à pied/en vélo/en voiture/en avion/en bateau/en avion

(22) institutions: German $=$ French $\neq$ English $^{8}$

a. go to school/church/work/hospital/prison

b. zur Schule/Kirche/Arbeit/ins Krankenhaus/Gefängnis gehen

c. aller á l'école/à l'église/au travail/à l'hôpital/en prison

(23) musical instruments: variation within English

a. play the piano/guitar/flute/saxophone/trombone (British English = Italian)

b. play piano/guitar/flute/violin (American English = German)

In cases like the preceding ones, we enter the domain of non-referential uses of definite articles, which may, therefore, often be omitted.

\section{Summary and conclusion}

Definite articles made their first appearance in European languages around the turn of the first millennium and are thus not a category inherited from Indo-European. What exactly triggered this development of demonstratives is discussed controversially in the relevant literature but it is quite plausible to assume that

8 Detailed corpus studies on variation in the use of the definite article across regional and textual varieties of English can be found in Hundt $(2016,2018)$. Most of the variation pointed out by her is a matter of "more or less" rather than "either-or". 
both their semantic and syntactic properties were involved in their development and grammaticalization. Leiss (2000) argues that it was the loss of aspectual distinctions and case inflection in Early Germanic that led to emergence of definite articles. Quantificational distinctions expressed in some languages by case distinctions (partitive versus accusative) or by verbal prefixes can be transferred to article systems. On the other hand, definite articles can be regarded as a natural extension in the meaning and use of adnominal demonstratives, also found in other subclasses of demonstratives. As far as their syntax is concerned, articles are structure builders, since they occur at the periphery of a noun phrase, either before or, more rarely, after all other modifiers of a noun phrase. In processing sentences, we know that the relevant constituent is a noun phrase, as soon as we meet an article (Hawkins 2004: 76).

It was the main goal of this paper to discuss the diversity in syntax, meaning and use of definite articles across languages, with a specific areal focus on Europe, and, in doing so, complement the typological picture presented in Dryer (2014). It was shown that such comparative studies need to have clear semantic foundations, which can be provided by formal explications of such notions as uniqueness, salience, existence and exhaustiveness, traditionally known to play a role in the semantic analysis of definite articles. On the basis of such a comparative basis, it is possible to reconstruct the historical development of definite articles in its basic outline and to distinguish different types. In addition to manifesting a variety of syntactic differences across languages, definite articles were also shown to differ strikingly in their use.

Acknowledgement: Johan van der Auwera, to whom this article is dedicated, successfully applied for a Humboldt fellowship during the academic year 1984-1985, which he intended to spend at the University of Hannover working with me. Unfortunately, I was invited to work at the NIAS as fellow-in-residence during the very same year. In spite of the subsequent logistic problems, we managed to initiate a fruitful co-operation, leading to many joint projects and publications. For the present paper, thanks are due to two anonymous reviewers for pointing out some errors and for making helpful suggestions. The usual disclaimers apply.

\section{References}

Abbott, Barbara. 2004. Definiteness and indefiniteness. In Laurence R. Horn \& Gregory Ward (eds.), Handbook of Pragmatics, 122-149. Oxford: Blackwell.

Behrens, Leila. 2005. Genericity from a cross-linguistic perspective. Linguistics 43 (2). 275344. 
Bosch, Peter. 2013. Schwache Definita und Verschmelzungsformen im Deutschen. Paper presented at the Ruhr-Universität Bochum, 5 February.

Bosch, Peter, Graham Katz \& Carla Umbach. 2007. The non-subject bias of German demonstrative pronouns. In Monika Schwarz-Friesel, Manfred Consten \& Mareile Knees (eds.), Anaphors in texts: Cognitive, formal and applied approaches to anaphoric reference, 145164. Amsterdam: John Benjamins.

Bosch, Peter, Tom Rozario \& Yufan Zhao. 2003. Demonstrative pronouns and personal pronouns: German der vs. er. Proceedings of the EACL2003: Workshop on the Computational Treatment of Anaphora.

Chesterman, Andrew. 1991. On definiteness: A study with special reference to English and Finnish. Cambridge: Cambridge University Press.

Clark, Herbert H. \& Catherine R. Marshall. 1981. Definite reference and mutual knowledge. In: Aravind K. Joshi, Bonni L. Webber \& Ivan A. Sag (eds.), Elements of discourse understanding, 10-63. Cambridge: Cambridge University Press.

Coppock, Elizabeth \& David Beaver. 2015. Definiteness and determinacy. Linguistics and Philosophy 38 (5). 377-435.

Dahl, Östen. 2004. Definite articles in Scandinavian: Competing grammaticalization processes in standard and non-standard varieties. In Bernd Kortmann (ed.), Dialectology meets typology, 147-180. Berlin: De Gruyter.

Davis, Henry, Carrie Gillon \& Lisa Matthewson. 2014. How to investigate linguistic diversity: Lessons from the Pacific Northwest. Language 90 (4). e180-e226.

De Mulder, Walter \& Anne Carlier. 2006. Du démonstratif à l'article défini. Langue Française 152 (4). 96-113.

De Mulder, Walter \& Anne Carlier. 2011. The grammaticalization of definite articles. In Bernd Heine \& Heiko Narrog (eds.), The Oxford handbook of grammaticalization, 522-535. 0xford: Oxford University Press.

Dryer, Matthew S. 2005. Definite articles. In Martin Haspelmath, Matthew S. Dryer, David Gil \& Bernard Comrie (eds.), The world atlas of language structures, 154-157. Oxford: Oxford University Press.

Dryer, Matthew S. 2014. Competing methods for uncovering linguistic diversity: The case of definite and indefinite articles. Language 90 (4). e232-e249.

Ebert, Karen H. 1970. Referenz, Sprechsituation und die bestimmten Artikel in einem nordfriesischen Dialekt. Breddtedt: Nordfriisk Institut.

Elbourne, Paul. 2010. The existence entailments of definite descriptions. Linguistics and Philosophy 33 (1). 1-10.

Elbourne, Paul. 2012. Definite descriptions. Oxford: Clarendon Press.

Etxeberria, Urtzi. 2014. Basque nominals: From a system with bare nouns to a system without. In Ana Aguilar-Guevara, Bert Le Bruyn \& Joost Zwarts (eds.), Weak referentiality, 335-364. Amsterdam: John Benjamins.

Frege, Gottlieb. 1984. Logical investigations. In Brian McGuiness (ed.), Collected papers on mathematics, logic and philosophy, 352 -371. Oxford: Basil Blackwell.

Gisborne, Nikolas. 2012. The semantics of definite expressions and the grammaticalization of THE. Studies in Language 36 (3). 603-644.

Greenberg, Joseph. 1990. How does a language acquire gender markers? In Keith Denning \& Suzanne Kemmer (eds.), On language: Selected writings of Joseph H. Greenberg, 241270. Stanford: Stanford University Press. 
Haspelmath, Martin. 1999. Explaining article-possessor complementarity: Economic motivation in noun phrase syntax. Language 75 (2): 227-243.

Haspelmath, Martin. 2001. The European linguistic area: Standard Average European. In Martin Haspelmath, Ekkehard König, Wulf Oesterreicher \& Wolfgang Raible (eds.), Language typology and language universals: An international handbook, volume 2, 1492-1510. Berlin: De Gruyter.

Hawkins, John A. 1978. Definiteness and indefiniteness: A study in reference and grammaticality prediction. London: Croom Helm.

Hawkins, John A. 2004. Efficiency and complexity in grammars. Oxford: Oxford University Press.

Heine, Bernd \& Tania Kuteva. 2006. The changing languages of Europe. Oxford: Oxford University Press.

Heinrichs, Heinrich M. 1954. Studien zum bestimmnten Artikel in den germanischen Sprachen. Giessen: Wilhelm Schmitz.

Himmelmann, Nikolaus P. 1997. Deiktikon, Artikel, Nominalphrase: Zur Emergenz syntaktischer Struktur. Tübingen: Niemeyer.

Himmelmann, Nikolaus P. 1998. Regularity in irregularity: Article use in adpositional phrases. Linguistic Typology 2 (3). 315-354.

Hundt, Marianne. 2016. Who is the/a/ $\varnothing$ professor at your university? A construction-grammar view on changing article use with single role predicates in American English. In Maria José López-Couso, Belén Méndez-Naya, Paloma Núñez-Pertejo \& Ignacio Palacios-Martínez (eds.), Corpus linguistics on the move: Exploring and understanding English through corpora, 227-258. Amsterdam: Rodopi.

Hundt, Marianne. 2018. Variable article usage with institutional nouns: An "oddment" of English? In Alex Ho-Cheong Leung \& Wim van der Wurff (eds.), The noun phrase in English: Past and present. Amsterdam: John Benjamins.

Joseph, Brian \& Irene Philippaki-Warburton. 1987. Modern Greek. London: Croom Helm.

Krámský, Jiri. 1972. The article and the concept of definiteness in language. The Hague: Mouton.

Lazard, Gilbert. 2012. The case for pure linguistics. Studies in Language 36 (2). 241-259.

Leiss, Elisabeth. 2000. Artikel und Aspekt: Die grammatischen Muster von Definitheit. Berlin: De Gruyter.

Löbner, Sebastian. 1985. Definites. Journal of Semantics 4 (4). 279-326.

Löbner, Sebastian. 2011. Concept types and determination. Journal of Semantics 28 (3). 279333.

Longobardi, Giuseppe. 1994. Reference and proper names: A theory of N-movement in syntax and logical form. Linguistic Inquiry 25 (4). 609-665.

Longobardi, Giuseppe. 2001. The structure of DPs: Some principles, parameters and problems. In Mark Baltin \& Chris Collins (eds.), The handbook of contemporary syntactic theory, 562-603. Oxford: Blackwell.

Louagie, Dana \& Jean-Christophe Verstraete. 2015. Personal pronouns with determining functions in Australian languages. Studies in Language 39 (1). 159-198.

Lyons, Christopher. 1999. Definiteness. Cambridge: Cambridge University Press.

Mosel, Ulrike \& Even Hovdhaugen. 1992. Samoan reference grammar. Oslo: Scandinavian University Press.

Moyse-Faurie, Claire. 1997. Grammaire du futunien. Nouméa: CDP de Nouvelle Calédonie.

Moyse-Faurie, Claire. 2016. Te lea faka'uvea / Le wallisien. Paris: Peeters. 
Neale, Stephen. 1990. Descriptions. Cambridge, MA: MIT Press.

Nocentini, Alberto. 1996. Tipologia e genesi dell'articolo nelle lingue europee. Archivio Glottologico Italiano 81 (1). 3-44.

Plank, Frans. 2003. Double articulation. In Frans Plank (ed.), Noun phrase structure in the languages of Europe, 337-396. Berlin: De Gruyter.

Russell, Bertrand. 1905. On denoting. Mind 14 (56). 479-493.

Schwarz, Florian. 2013. Different types of definites cross-linguistically. Language and Linguistics Compass 7 (10). 534-559.

Schwarz, Florian. 2014. How weak and how definite are Weak Definites? In Ana Aguilar-Guevara, Bert Le Bruyn \& Joost Zwarts (eds.), Weak referentiality, 213-235. Amsterdam: John Benjamins.

Sperber, Dan \& Deidre Wilson. 1996. Relevance: Communication and cognition. Oxford: Blackwell. 